\title{
八一ドパン破砕を伴う乾燥地植林における 土壌化学性評価による持続可能性の検討
}

\author{
濱野裕之 1)2）斉藤則子 1）加藤 茂 1） 北原弘道 3) \\ 高橋 伸英 3)山田興一 1)2）小島 紀徳 1)2) \\ 1)成蹊大学 理工学部物質生命理工学科 \\ (下180-8633 東京都武蔵野市吉祥寺北町3-3-1) \\ 2)エディスコーワン大学 自然科学科生態システムマネージメントセンター \\ (Joondalup, WA 6027, Australia) \\ 3)信州大学 繊維学部 精密素材工学科 \\ (テ386-8567 長野県上田市常田3-15-1)
}

乾燥地における大規模植林による炭素固定のための技術確立が求められている. 乾燥地に降る貴重な降雨を有効に 利用するために，不透水層破壊による土壌構造改善技術の導入，および土盛りによる堰（Bank）を築いた西オース トラリア州レオノラ近郊を対象とした植林実証試験が行われている.

本研究では, 集水技術導入による塩類の供給, 蓄積の変化に焦点をあて, Bank内の土㙵掞よび雨水, 表面流出水, 灌水の化学性評価から, 集水に伴う塩類集積状況の把握を行った. Bank造成および植林開始から 5 年経過時点では塩 害発生には至っていないが, Bank外と比べ中では電気伝導度, 水溶性イオン濃度共に高く, ゆっくりとではあるが 蓄積していることが示唆された.

また，元素ごとに供給源の水を特定した． $\mathrm{Na}, \mathrm{Ca}, \mathrm{Mg}$ は主に灌水より供給されており，灌水の供給を止めた現在 以降は蓄積の恐れが無いと期待された。一方, 植物必須元素である $\mathrm{K}, \mathrm{P}$, 主に雨水より供給されている. 土壤の 化学分析の結果からも根域での濃度が裸地部と比べ高く, リターや樹幹流による土壤への還元があると考えられる.

キーワード : 植林, 塩類集積, 電気伝導度, 水溶性イオン, 乾燥地

\section{I 、はじめに}

地球規模で問題となっている温暖化の主な原因物 質である二酸化炭素の効果的な削減が急務となって いる。 その方法の一つとして, 大規模乾燥地を利用 した植林による炭素の陸上固定が考えられており, その技術の確立が求められている. 現在, 西オース トラリア州レオノラ近郊の乾燥地を対象地としてそ の検討が進められている（Yamada et al., 1999). 対 象となる乾燥地では，植物成長に必要な水が大変少 ないため，限られた降雨を有効に利用することが極 めて重要となる（安部ら，1997）。現状の土壇状態 を利用して樹木を育てるだけでは，この貴重な降雨 を有効に利用することができないことから, 土層改 良を施した植林サイトを設け実証試験を行ってい る. 本研究で対象としたサイトでは, 不透水層破壊 による土壤構造改善技術を導入し, 土盛りにより堰
（Bank）を築くことで, 表面流出した降雨をBankの 内側の領域に集水し，樹木へ供給されるように改良 を行った．集水技術は「ウォーター・ハーベスティ ング」と呼ばれ，数千年前から中東，マグレブを中 心に行われている。集水域を人工的に整備し, でき るだけ多くの流出水を集めて目的地に導水し，作物 栽培などに有効に利用する伝統的利水システムであ る(水文・水資源学会, 1997). 集水効果を得るため には，Bankの造成などが行われる。しかしながら， 表面流出水は土壤表面を流れてくる途中で, そこに 含まれる塩類を溶出し，同時に運んでしまうことが 考えられる.そのため, 長期間集水を継続すること により, 植林地が塩害化し, 植林樹木の成長を阻害 する可能性がある。そこで本研究では, 植林地にお ける土壤の塩類蓄積挙動を明らかにし, 塩害化の可 能性を検討する。また,このサイト内に植樹された 
樹木には，ある時期までは定期的に地下水汲み上げ による灌水がなされており, 灌水による塩類蓄積も 評価する必要がある。

本報告では, サイト内土畩, 雨水, 表面流出水, 灌水の化学性評価から, Bank造成による集水に伴 う塩類集積状況を把握した。従来, 乾燥地において 大規模なBankを設け，植林実証試験を行っている 場所での塩類挙動の測定例はほとんど見られず，今 後の植林技術確立の上でも貴重なデータが得られた と考えられる。

\section{II ．調查地および测定方法}

\section{1. 実験対象地の概要}

本研究は, 年間降水量 $200 \mathrm{~mm}$ 前後である西オー ストラリア州レオノラ近郊に設けられている植林地 にて行われた。この対象地内には, 複数の実証植林 試験サイトが設けられている (Kojima et al., 2007).

植林サイトの中でもSite Cは, 土壤改善技術求よ び集水技術を施した最も規模の大きい試験地である (Shiono et al., 2007, Yamada et al., 2003, 山田ら, 2005)。本サイトでは，本来表面流出し塩湖に流入 する水を土盛りにより集水し，その水を $400 \mathrm{~m} \times$ $600 \mathrm{~m}$ のサイト内供給するようにBank と呼ばれる 堰を築いた。さらにBankで囲まれた内側には，や はり土盛りにより13個のPondと呼ばれる植林エリア （約 $50 \mathrm{~m} \times 50 \mathrm{~m} ）$ を造成した。この地域では，地下 にハードパンと呼ばれる不透水層が存在する。これ を7 m間隔で爆破により破砕し, 破砕した穴に1999 年7月に植樹した（ただし，破砕効果評価のため Pond 5だけは未破砕である)。これらの樹木には， 植林から 5 年 8 ケ後の 2005 年 3 月まで毎月一度, Bank近くの井戸より地下水を汲み上げて灌水を行っ た（灌水の水盤半径は約1-1.5 m). さらにその後 1 年 間は 2 ケに 1 度灌水を行った。また，Bankの入口 (Inlet：幅 $1 \mathrm{~m}$, 深さ $0.9 \mathrm{~m}$ ) 拉よび出口 (Outlet：幅 $1 \mathrm{~m}$ ，深さ $0.7 \mathrm{~m} ）$ には，それぞれサイトへの表面流 出水の流入量抢よびサイトからの流出量測定のため に流量計 (Unidata, Starflow System 6526-21) を設置 し，さらにサイト内には降雨計（Unidata, Tipping Bucket Rainfall Gauge 6506A）も設け，常時測定を 行った.

\section{2. 測定方法}

\section{1) 試料採取方法}

本研究の対象地としたSite Cより，2002年7月およ び2004年3月に土壤試料を採取した。採取地点を 図ー1に示す。Bank内裸地部（Pond外）より7点, Pond 4 (ハードパン破砕有り) 抢よびPond 5 (ハー ドパン破砕無し), Bank入口（Inlet）および出口 (Outlet), さらにBank内側との比較のためにBank外 側より1点の, 計12点とした。また, Pond内につい ては植林木根元（ハードパン破砕部，樹木から約 $50 \mathrm{~cm}$ で灌水水盤半径内）㧍よび裸地部（未破砕部） の両方から土壤を採取した。2002年7月には表層土 のみ採取した。2004年3月には, 各採取地点で複数 箇所に検土杖を挿入し，それぞれハードパンが存在 する約20-30 cmまでの土壤を $10 \mathrm{~cm}$ 間隔で採取した. 試料採取はハードパン深さまで行っているため, 地 点毎に採取深さは異なっている。サンプルは筒状で ある検土杖により土壤をボーリングし，0-10，10-20， 20-30 cmそれぞれの間に存在する全土畩とした。

また，このSite内への供給水源として，Inletより の表面流出水, Site C内の雨水, さらには灌水に使 用している地下水の 3 試料を，偶然降雨があり，こ れらを得ることができた2002年7月に採取し，分析 に供した。

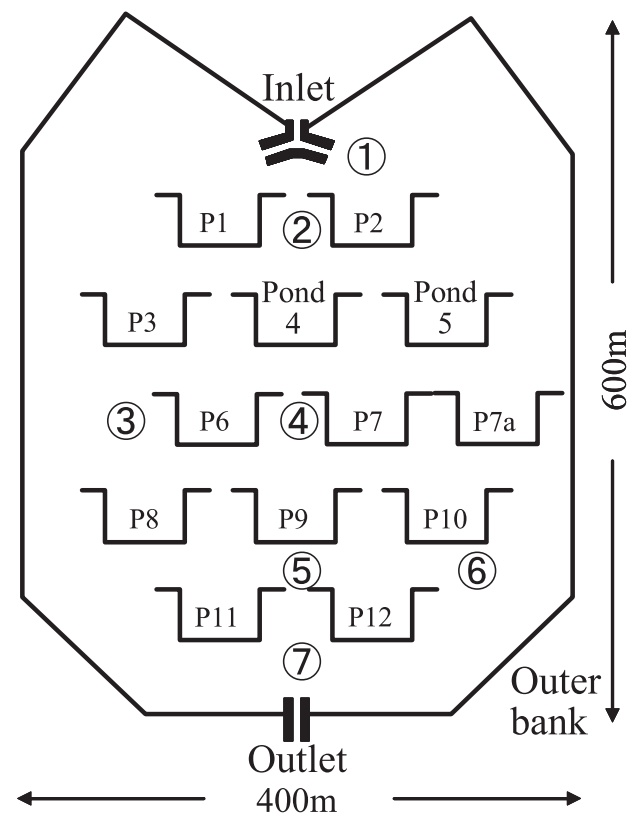

図-1 Site C概略図および土壤サンプル採取地点

Fig.1 The map of Site $\mathrm{C}$ and sampling points. 


\section{2）測定方法}

採取した土壤は, 約 $40{ }^{\circ} \mathrm{C}$ の恒温槽にて風乾させ た後, 測定に使用した。本研究では, 水溶性イオン 濃度, 電気伝導度 ( $\mathrm{EC}_{1: 5}$ 值), $\mathrm{pH}$ の測定を行った。

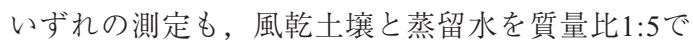
混合させて抽出する「1:5水抽出法」(土壤養分分析 測定法委員会, 1997, 地盤工学会, 2000, 和田ら, 1994）を用いて行った。混合物を，振とう機 （200 rpm）を用いて室温にて約6時間振とうさせた。 その後, 遠心分離 $(10000 \mathrm{rpm}$, 約 $10 \mathrm{~min})$ により混 合物内の土壤と上澄み液を分離した。さらに上澄み 液は $0.45 \mu \mathrm{m}$ フィルターによりろ過をした。

このろ液をサンプル液とし, EC值抢よび $\mathrm{pH}$ 各 值をECメーター（YOKOGAWA， SC82）, pHメー ター（SENSONIX JAPAN，PS-101B）によりそれぞ れ直接測定した。水溶性イオンとして, $\mathrm{Na}, \mathrm{Mg}$, $\mathrm{K}, \mathrm{Ca}$ については50倍に希釈した溶液をICP-MS （島津製作所，ICPM-8500）を用いて，Pについては モルブディックブルーアスコルビン酸法 (Watanabe et al., 1965）によりUV吸光度計（島津製作所, UV1700）を用いて，それぞれ濃度の測定を行った。ろ 液中の濃度と土壤: 水重量比から, 土壌単位重量当 りの元素量を得た。

各種の水サンプルについては, ICP-MSを用いて $\mathrm{Na}, \mathrm{Mg}, \mathrm{K}, \mathrm{Ca}, \mathrm{P}$ の含有濃度を測定した。

\section{III. 結果及び考察}

\section{Bank造成5年経過時点の土䁃化学性評価}

各地点に扔ける土壤からの抽出水の化学性評価（水 溶性イオン濃度, $\mathrm{EC}_{1: 5}$ 值, $\mathrm{pH}$ ) 結果を図一2 a) - g ) に示す.ここで図ー2 a) - e) 中の棒は土壤中の水溶 性元素イオン量を示す. 図中の中段右のnote1に各元 素についてのスケールを示した。ここで白い棒は樹 木直下を，黒い棒は裸地を示すが，Pのみについては スケールが20倍異なる。また，図－2ff，g）の $\mathrm{EC}_{1: 5}, \mathrm{pH}$ についてのスケールは, 図中の下段右note2 に図示した。いずれの地点も複数のサンプルにより
測定を行ったが，同じ深さ毎に濃度の平均值を求め, 図に示した。図にはこれらの結果を, サンプル土壤 採取地点の位置と合わせて揭載した。

図一2 a) - e）より，土壤裸地部での比較を行うと, いずれの塩類もBank外と比べて中では濃度が高いこ とが確認された。これは，集水と共に塩類が運ばれ， あるいは灌水により塩類が移入され蓄積したものと 考えられる。この傾向は各Pondについても確認され た。また, $\mathrm{Na}, \mathrm{Mg}, \mathrm{Ca}$ 3元素については, 土壤の 深部ほど濃度が高くなる傾向が見られた。一方，K およびPについては, 深さ方向への偏りは見られず, ほぼ均一に含有していた。ささらにPond内土壤では，P 以外の4元素については樹木根元土壤では裸地部に比 ベて含有量が少なかった。これは明らかに, 樹木が 成長に必要として使用したためであると考えられる。 一方，Pも植物成長には必要不可欠な元素であり，他 の元素と同様に樹木成長に使われていると考えられ るが，樹木根元土壤で非常に高い傾向が確認された。 Pは根から吸収されると共に, 樹木からリターや樹幹 流として表層に供給されるためであると考えられる。 いずれも植物にとって必要とされるKと $\mathrm{P} て ゙$ 若干傾向 が異なることは興味深い.

図一2 f) より，いずれの地点の $\mathrm{EC}_{1: 5}$ 值も塩害基準 值であると考えられている $0.4 \mathrm{dS} / \mathrm{m}$ （伊藤, 1984）に は達しておらず, Bank造成5年では塩害は起きてい ないことが確認された。しかし，水溶性イオンが Bank外と比べ内側土壤の方が多く含有していること からも分かるように, 表面流出水や灌溉水に含まれ る塩類はほとんどBankの外側へ流れ出ずに内側に集 積したため, 若干Bank外側と比べてEC值が高くなっ たと考えられる.

図一2 g)より, 元々の土壌状態に近い裸地部では pHはほぼ酸性から中性を示したが, 樹木根元土壤で はアルカリ性であった. 樹木根元では水溶性Pイオン 濃度が高かったことからも推定されるように，リン 酸ナトリウムやリン酸カリウムと言った塩が存在す ることにより，アルカリ性を示したと考えられる。 
a) $\mathrm{Na}$ (Sodium)

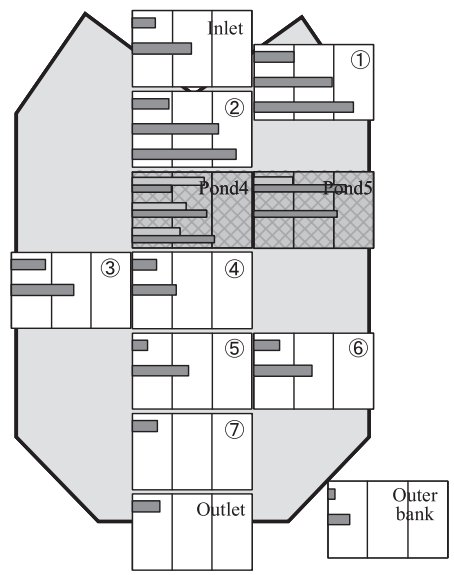

d) K (Potassium)

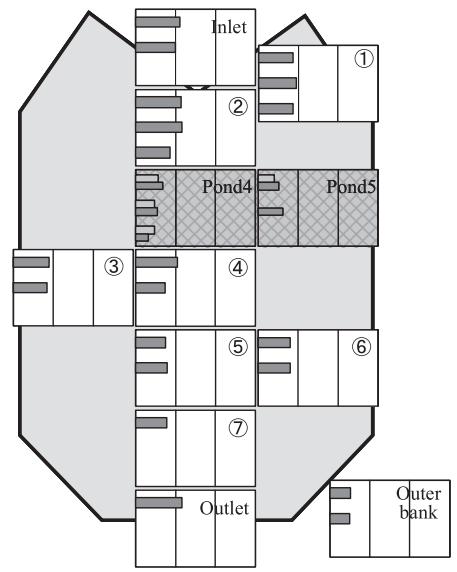

f)Electrical conductivity $\left(\mathrm{EC}_{1: 5}\right)$

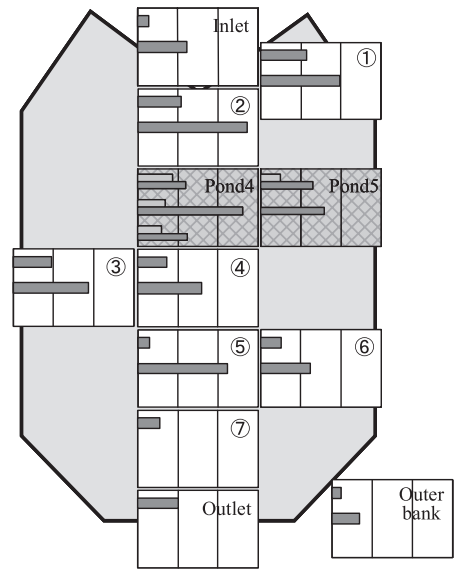

b) $\mathrm{Mg}$ (Magnesium)

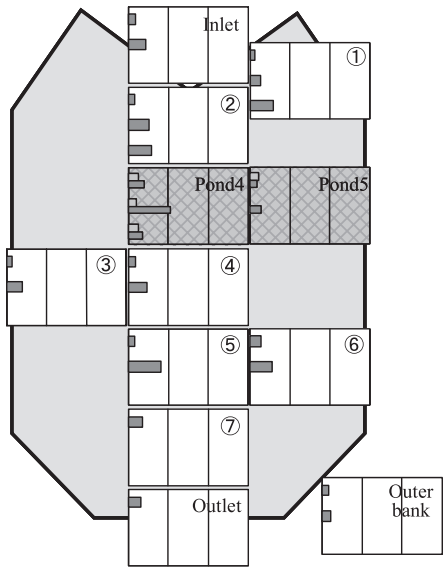

e) P (Phosphorus)

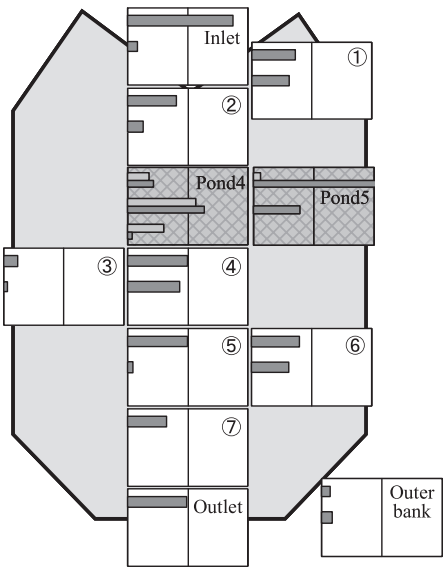

g) $\mathrm{pH}$

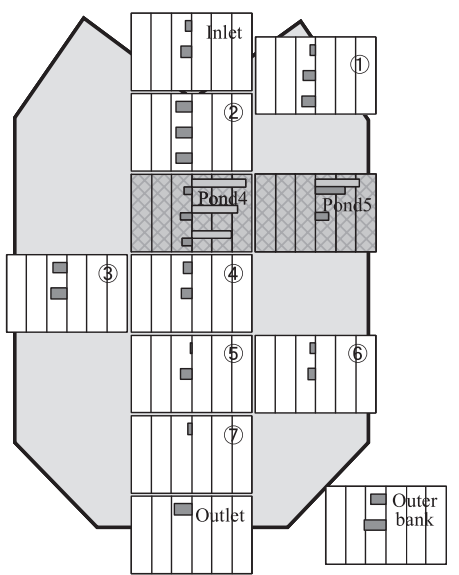

c) $\mathrm{Ca}$ (Calcium)

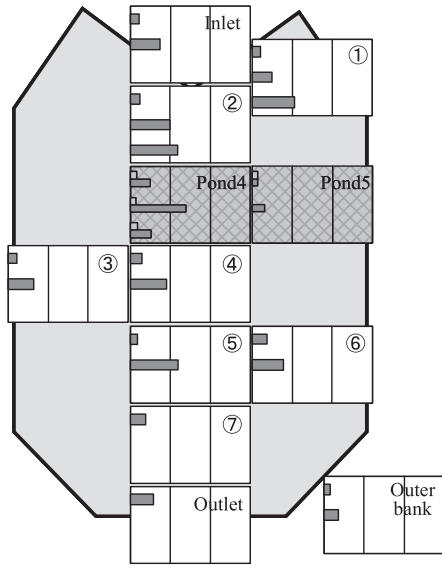

note1) Axes values for elements

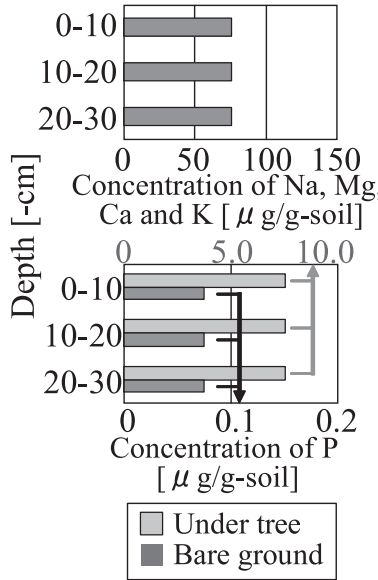

note2) Axes values for $\mathrm{EC}_{1: 5}$ and $\mathrm{pH}$

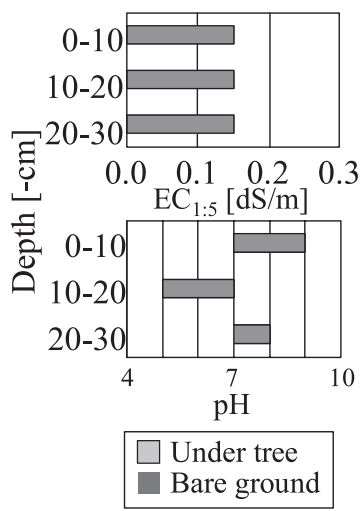

図－2 Site Cにおける各地点の水溶性イオン濃度 $(\mathrm{a})$ ナトリウム $(\mathrm{Na}), \mathrm{b})$ マグネシウム $(\mathrm{Mg}), \mathrm{c})$ カルシウム $(\mathrm{Ca}), \mathrm{d})$ カリウ ム $(\mathrm{K}), \mathrm{e})$ リン $(\mathrm{P})), \mathrm{f})$ 電気伝導度 $\left(\mathrm{EC}_{1: 5}\right)$ および $\left.\mathrm{g}\right) \mathrm{pH}$ (2004年3月測定)

Fig.2 Concentrations of water-soluble ions (a) sodium, b) magnesium, c) calcium, d) potassium, e) phosphorus), f) electrical conductivity and g) $\mathrm{pH}$ at each point in Site C (measured on March 2004). 


\section{Site内塩類の供給源の特定}

本研究で測定した各水サンプルの種類，1999年7 月より2004年3月の間（57ケ月）のSite Cで測定され た降雨量, 流入量 (Inlet) と流出量 (Outlet), 灌水 量それぞれの積算值，および塩類濃度の測定結果を 表一1に示す.

表一1に示した流入水の塩類分析值に流入量一流出 量の水量をかけたものを，流入により運ばれた塩類 量とした。また表一1に示した降雨量は，57ケ月間で の全降雨量 $[\mathrm{mm}]$ にSite Cバンク内面積 $152,300 \mathrm{~m}^{2}$ を かけて体積とした。この水量に測定した雨水の塩類 濃度をかけて, 降雨による供給量を求めた。一方灌 水は, 一ヶ月に一度, 1 本の樹木に与えた水量から 57ケ月間での総量を計算し，それに各Pond内の樹木 本数をかけ, さらにSite C内全てのPondのこの総水 量を積算し表一1に示した.この水量に表一1の塩類 濃度の值をかけて塩類流入量を得た. Bank内に供給 された 3 種の水の各イオン濃度測定結果および各供給 水量（Bank造成から土壤サンプル採取時点までの 57 ケ間）を図一-3に示す。図一3の5本の棒グラフ の内, 最も右の図は流入水の起源をそれぞれ3種の水 源に分けて流入量で示した (右縦軸). 最も左の棒グ ラフは, $\mathrm{Na}$ の流入起源を 3 種の水源に分けて示した (左縦軸)。これに続く3本ずつの棒は同様に $\mathrm{Mg}, \mathrm{Ca}$, Kについて示したものであるが，Naに比べ棒の長さ を10倍にして表示した (同様に左縦軸). 右から2番 目の棒は同様にPについて示したものであるが，棒の 長さはNaに比べ100倍となっている (同様に左縦軸).

この結果より，この57ケ月間にBank内へ供給さ れた水の大部分が, 雨水からの供給であったことが 分かる。また, Bank内への塩類供給は, $\mathrm{Na}, \mathrm{Mg}$, Caについては灌水から，K拈よびPについては雨水

表-1 1999年7月から2004年3月までの間にSite C内に 供給された各水量と供給水内塩類濃度

Table 1 Various water amount into Site C between July 1999 and March 2004, and ions concentration in each water (measured on July 2002).

\begin{tabular}{l|c|c|c|c|c|c}
\hline & Amount & \multicolumn{6}{|c}{ Ions concentration in each water } \\
\cline { 2 - 7 } & $\mathrm{Gg} / 57$ months & \multicolumn{5}{|c}{$\mathrm{mg} / \mathrm{kg}$} \\
\hline & & $\mathrm{Na}$ & $\mathrm{Mg}$ & $\mathrm{K}$ & $\mathrm{Ca}$ & $\mathrm{P}$ \\
\hline Rainfall & 205 & 2.20 & 0.45 & 1.76 & 0.92 & 0.27 \\
\hline Irrigation & 12.7 & 211.00 & 36.00 & 3.00 & 44.00 & 0.01 \\
\hline Inlet & 38.6 & & & & & \\
\hline Outlet & 13.0 & \multirow{2}{*}{2.90} & 0.64 & 5.30 & 1.20 & 0.00 \\
\hline Inlet-Outlet & 25.7 & & & & & \\
\hline
\end{tabular}

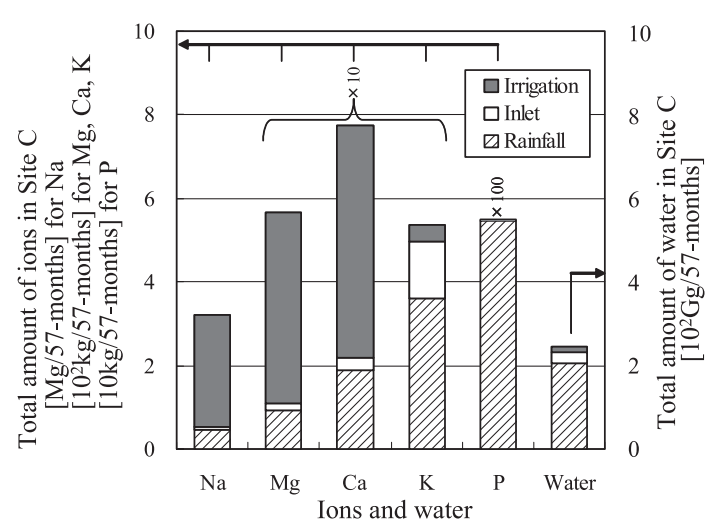

図－3 1999年7月-2004年3月の間にSite Cへ流入した水 および塩類の供給源別割合

Fig.3 Ratio of ions and water resources into Site $\mathrm{C}$ between July 1999 and March 2004.

からの供給が最も多いことが明らかとなった.

この土壤へは2005年3月以降灌水が止められている ことから，今後のBank内への塩類供給源は雨水㧍よ び表面流出水のみとなる。植物には, 適度な栄養塩 の供給が必要とされるが, 樹木成長に伴う土壤栄養 塩の収奪により栄養塩不足となり樹木成長の制限が 起こるか, 塩害防止と併せて植物への栄養塩類供給 の両面からの継続的な測定が必要であると言える.

\section{Site内塩類集積状況の評価}

Bank内土壤の塩類集積状況を図一4に示す。 2002 年7月および2004年9月の 2 回の水溶性イオンの測定 結果を用いて考察する。図中では，いずれも表層土 壤の含有量測定結果のみを示した。複数採取点のあ るPond外については平均值により示した。また， 2 つのPondについては, 樹木根元と裸地部を分けて示 している.

これらの結果より，集水による塩類集積が考えら れるPond外の裸地部土壤では，Caを除く $\mathrm{Na}, \mathrm{Mg}$ ， Kの含有量が多くなった傾向が見られた. Pond内で はハードパン破砕の有無による違いは見られず，二 つのPond共に同様の傾向が確認された。すなわち， 裸地部土壤ではいずれの元素も含有量が少なくなっ ているが, 樹木根元土畩では $\mathrm{Na}$ を除く全ての元素 で多くなっていた。塩害発生の主要原因と考えられ る $\mathrm{Na}$ の上昇がほとんど見られず，その他の元素を 見ても最も塩類濃度上昇が大きかった樹木根元土壤 のKで約 $10 \mu \mathrm{g} /(\mathrm{g} \cdot \mathrm{y})$ と非常に蓄積速度は遅いと 言え，樹木が成木に成長するまでに要すると言われ 


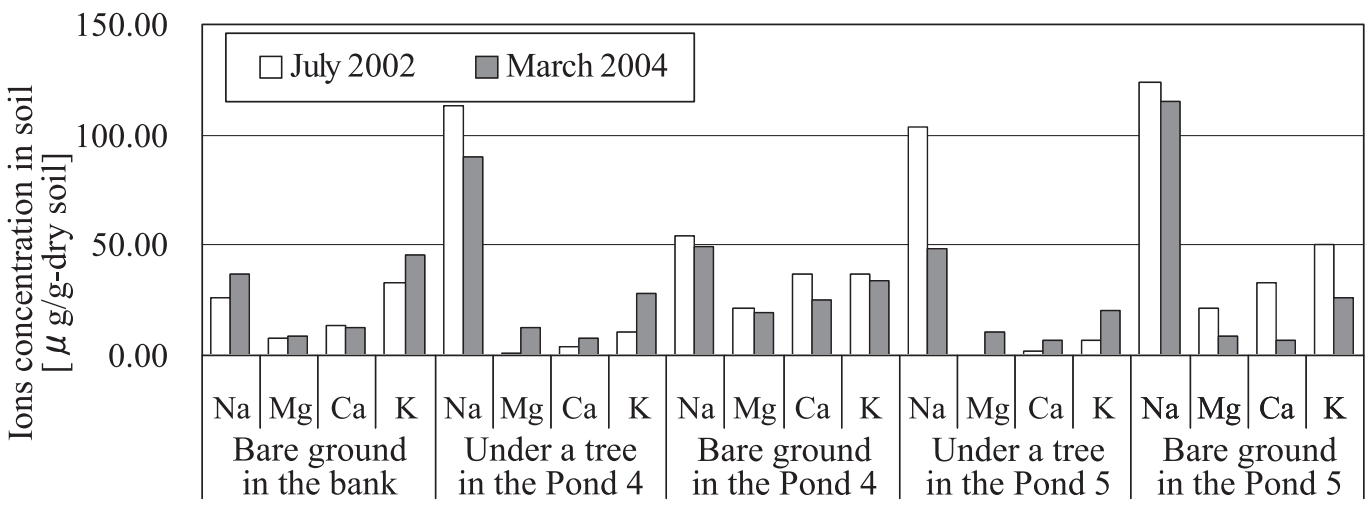

Sampling points and ions

図-4 Site C内各地点土壤の水溶性イオン濃度の2002年7月と2004年3月の比較：Pond 4はハードパン破砕, Pond 5 は無し

Fig.4 Comparison between July 2002 and March 2004 of concentrations of water-soluble ions at each point in Site C (with and without hardpan blasting for pond 4 and 5 respectively).

ている20年では，あまり影響が無いと本報告からは 考えられる。しかしながら, 今後更なるデー夕測定 を加えた上での継続的な評価の実施が望まれる。

\section{IV.まとめ}

乾燥地大規模植林実証テス卜地での集水を目的と したBank造成により懸念されていた樹木成長阻害 となる塩類集積について, 造成・植林から約 5 年後 の土潩化学性の測定により評価を行った。 5 年経過 時点でも，土壤EC值は塩害基準值である $0.4 \mathrm{dS} / \mathrm{m} に$ は達していないことが確認された。しかし, Bank 内水溶性イオン濃度はBank外よりも高くなってお り，少しずつではあるが集積していたと言える。

Bank内への塩類供給源を特定し, $\mathrm{Na}, \mathrm{Mg}, \mathrm{Ca}$ ついては灌水，K扔よびPについては雨水が主な供 給源であることを確認した。また，塩類の蓄積速度 は非常に遅いことが確認された。

前者3元素の主な供給源である地下水を汲み上げ た灌水は現在ではすでに停止しており，今後の供給 源は雨水打よび表面流出水のみとなる。このことか らも, 今後はさらに塩類集積が緩やかになると考え られ，樹木が成木に成長するまでに要すると言われ ている20年ではあまり影響が無いと考えられる。 Tanouchi et al.（2006）の報告のように, 灌水停止後 も無降雨期が長く続いたにも関わらず，良好な成長 を続けている。これらのことから，植林後の若干年 は灌水が必要としても，そのことによる $\mathrm{Na}, \mathrm{Mg}$, $\mathrm{Ca}$ の蓄積の恐れは少ない.
しかしながら，植物にとってはK，Pなどについ ては, 特に栄養塩としての適度な供給を必要として いる．本報では，リターや樹幹流による土壤へのK, Pの還元があると推測されたが，植物への栄養塩類 供給と循環の点については今後も継続的な測定が必 要であると言える。

\section{謝辞}

本研究は，科学技術振興事業団 (現科学技術振興 機構）・戦略的基礎研究「乾燥地植林による炭素固 定システムの構築」および, 環境省地球環境研究総 合推進費S-2によって実施された。ここに記し，謝 意を表する。

\section{参考文献}

安部征雄・小島紀徳・山田興一 (1997) : 二酸化炭素対策として の乾燥地における大規模植林, 沙漠研究, 7 (1), pp.77-81.

土壤養分測定法委員会 (1997): 土壤養分分析法, 養賢堂, pp.45-52.

伊藤純雄 (1984): 施設栽培における新実用化技術[3] 土壌溶液 に基づく施設内土潩診断と管理(2), 農業および園芸, 59 (8), pp.1081-1088.

地盤工学会 (2000): 土質試験の方法と解説 一第一回改訂版一, 社団法人地盤工学会, pp.170-185.

Kojima T, Hamano H, Abe Y, Tanouchi H, Egashira Y, Saito M, Law J, Takahashi N, Yamada K. 2006. Basic Data of Research Project on Large Scale Afforestation of Arid Land for Carbon Fixation near Leonora in Western Australia. Journal of Arid Land Studies 16 (3) : 167-174.

Shiono K, Abe Y, Tanouchi H, Utsugi H, Takahashi N, Hamano H, Kojima T, Yamada K. 2007. Growth and Survival of Arid Land Forestation Species (Acacia aneura, Eucalyptus camaldulensis and E. salubris) with Hardpan Blasting. Journal of Arid Land 
Studie 17 (1) : 11-22.

水文・水資源学会 (1997) : 水文・水資源ハンドブック, 朝倉書店, pp.590-602.

Tanouchi H, Utsugi H, Takahashi N, Hamano H, Kawarasaki S, Kojima T, Yamada K. 2006. Water Use Efficiency of Trees in Arid Lands: Plasticity to Water Conditions. Journal of Arid Land Studies 15 (4) : 267-270.

和田信一郎・角藤やす子・小田原孝治・古村秀麾（1994）：7点 の施設土䁃における水分含量変化にともなう土壤溶液イオン組 成の変化, 日本土壇肥料学雑誌, 65 (5), pp.530-537.

Watanabe FS, Olson RS. 1965. Test of an Ascorbic Acid Method for Determining Phosphorus in Water and $\mathrm{NaHCO}_{3}$ Extracts from Soil. Soil Science Society Proceedings 29:
677-678

Yamada K, Kojima T, Abe Y, Saito M, Egashira Y, Takahashi N, Tahara K, Law J. 2003. Restructuring and Afforestation of Hardpan Area to Sequester Carbon. Journal of Chemical Engineering of Japan 36 (3) : 328-332.

山田興一・小島紀徳・安部征雄・江頭靖幸・田内裕之・高橋伸英・ 濱野裕之・田原聖隆 (2005) : 乾燥地植林による炭素固定システ 厶構築 一土壇構造改良による炭素固定促進一, エネルギー・資 源, 26 (6), pp.57-63.

Yamada K, Kojima T, Abe Y, Williams A, Law J. 1999. Carbon Sequestration in an Arid Environment near Leonora, Western Australia. Journal of Arid Land Studies 9 (2) : 143-151.

(受付：2007年1月18日，受理：2007年8月3日）

\title{
Discussion on Sustainability of Arid Land Afforestation with Hardpan Blasting from Soil Chemical Assessment
}

\author{
Hiroyuki HAMANO ${ }^{12)} \quad$ Noriko SAITO ${ }^{1)}$ Shigeru KATO ${ }^{1)}$ Hiromichi KITAHARA ${ }^{3)}$ \\ Nobuhide TAKAHASHI $^{3)}$ Koichi YAMADA 1)2) Toshinori KOJIMA 1)2) \\ 1) Department of Materials and Life Science, Seikei University \\ (3-3-1, Kichijoji-kitamachi, Musashino-shi, Tokyo 180-8633, Japan) \\ 2) Centre for Ecosystem Management, School of Natural Sciences, Edith Cowan University \\ (Joondalup, WA 6027, Australia) \\ 3) Department of Fine Materials Engineering, Shinshu University \\ (3-15-1, Tokida, Ueda, Nagano 386-8567, Japan)
}

The establishment of technologies for carbon fixation by large-scale afforestation on arid lands is required. Afforestation has been tested at a pastureland near Leonora, Western Australia where hardpan blasting and bank construction were conducted for effectively use of limited rainfall in the arid area.

In the present paper, the change of salt provision and accumulation by the change of water movement has been focused. Salt accumulation tendency was checked by chemical assessment of soils and waters of rainfall, surface runoff water and irrigation water in the afforestation trial site. Both of electrical conductivity and concentrations of water-soluble ions of the soils in the area surrounded by the bank were higher than those at the outside of the area, which indicates that salt accumulation was slowly and gradually proceeding, although the salt damage has not become evident yet five years after the start of the afforestation trial.

The source of each chemical element measured was identified. $\mathrm{Na}, \mathrm{Ca}$ and $\mathrm{Mg}$ were mainly supplied from irrigation, and therefore, their accumulation is expected not to proceed any longer because irrigation was stopped. On the other hand, the source of $\mathrm{K}$ and $\mathrm{P}$ that are essential elements of plants was found to be rain water. It cleared that the soil concentrations of $\mathrm{K}$ and $\mathrm{P}$ under tree were higher than that of bare soil, and it estimated that $\mathrm{K}$ and $\mathrm{P}$ are returned into soil from litters and stemflow of plants.

Key words : afforestation, salt accumulation, electrical conductivity, water-soluble ion, arid land 